Acknowledgement
\begin{tabular}{|l|l|l|}
\hline Neuroepidemiology 1982;1:249 & Bruce S. & $\begin{array}{l}\text { Schoenberg, } \\
\text { Ed.-in-Chief }\end{array}$ \\
\hline
\end{tabular}

\title{
Acknowledging the Contributions to Neuroepidemiology
}

During its initial year, Neuroepidemiology has attempted to establish high scientific standards for papers accepted for publication. Despite its youth, the journal has been recognized with an Award of Merit from the Society for Technical Communication.

Perhaps the three critical factors necessary for a successful publication are authors who report work of high quality, an Editorial Board and panel of ad hoc reviewers who carefully evaluate submitted manuscripts, and a publisher who takes meticulous care in the preparation of the final product. I wish to express my appreciation to each of these individuals and to acknowledge, with special thanks, the help of the ad hoc reviewers who do their work in anonymity. Their names are as follows:

John F. Annegers, PhD Gary Beringer, Dr PH Nadir Bharucha, MD Jacob Brody, MD Juan Cabrera, MD James Cereghino, MD Clarence J. Gibbs, PhD Eldon Eagles, MD, Dr PH Lois Elliott, PhD Armin Haerer, MD W. Allen Hauser, MD Robert Katzman, MD Emre Kokmen, MD Jess Kraus, PhD

Alan Leviton, MD E. Wayne Massey, MD Kenneth Nikano, MD, MPH J. Kiffin Penry, MD A. Bernard Pleet, MD Roger Porter, MD John Richert, MD William Sibley, MD Peter Spencer, PhD Alexandre TodoroSc MD Barbara Visscher, MD, Dr PH Sylvia Wassertheil-Smoller, PhD Jack P. Whisnant, MD

B. But no journal can be successful without readers. I hope our efforts and performance will merit your continued interest in and support of Neuroepidemiology. 